\title{
Systemic and neurotoxic effects of epidural meloxicam in rabbits
}

\author{
Gracineide da Costa Felipe $^{{ }^{*}}$ Fernanda Vieira Henrique ${ }^{1}$ Renato Otaviano do Rego ${ }^{1}$ \\ Alane Pereira Alves ${ }^{1}$ Kalyne Danielly Silva de Oliveira ${ }^{1}$ Millena de Oliveira Firmino ${ }^{1}$ \\ Lylian Karlla Gomes de Medeiros ${ }^{1}$ Gustavo de Assis Silva ${ }^{1}$ Luanna Figueirêdo Batista ${ }^{2}$ \\ Antônio Flávio Medeiros Dantas ${ }^{2}$ Bonifácio Benicio de Souza ${ }^{2}$ Pedro Isidro da Nóbrega Neto ${ }^{2}$
}

\footnotetext{
'Programa de Pós-graduação em Medicina Veterinária (PPGMV), Universidade Federal de Campina Grande (UFCG), Avenida Universitária, s/n, Jatobá, 58708-110, Patos, PB, Brasil. E-mail: neyde19@gmail.com. "Corresponding author.

${ }^{2}$ Unidade Acadêmica de Medicina Veterinária, Universidade Federal de Campina Grande (UFCG), Patos, PB, Brasil.
}

\begin{abstract}
The aim of this study was to assess systemic and neurotoxic changes following an epidural administration of meloxicamin to rabbits. Twelve adult rabbits four males and eight females; average mass, $1.9 \pm 0.1 \mathrm{~kg}$ were randomly divided into two groups: a control group $(G C)$, which received a single dose of $0.9 \%$ NaCl epidurally in a volume of $0.3 \mathrm{~mL} \mathrm{~kg}^{-1}$ and a meloxicam group $(G M)$, which received $0.2 \mathrm{mg} \mathrm{kg}$ meloxicam epidurally along with $0.9 \% \mathrm{NaCl}$ in a total volume of $0.3 \mathrm{~mL} \mathrm{~kg}^{-1}$. Heart rate, respiratory rate, body temperature, and neurological abnormalities were assessed prior to administration of anesthesia (HO), 1, 2, 3, 6, 12, and 24h following epidural puncture (H1, H2, H3, H6, H12, and $H 24$, respectively), and every $24 \mathrm{~h}$ afterward for 10 days after epidural puncture (D2, D3, D4, D5, D6, D7, D8, D9, and D10). The surface temperature of lumbosacral region was also measured at $\mathrm{HO}, \mathrm{H1}, \mathrm{H6}, \mathrm{H12}, \mathrm{H24}, \mathrm{D} 5$ and D10. Three animals from each group were euthanized on days 15 and 30 after epidural puncture to assess possible spinal injuries. Variances observed in physiological parameters were not suggestive of adverse effects of meloxicam, as all were within the reference standards, and there were no physical or behavioral changes observed. Neurological function was similar between groups, with only difference between baseline values and values $1 \mathrm{~h}$ after epidural administration in both groups. There were no histopathological changes in the GM group, and only one animal showed discrete lymphocytic infiltrate. Epidural lumbosacral administration of meloxicam at a dose of $0.2 \mathrm{mg} \mathrm{kg}^{-1}$ caused no significant systemic or neurotoxic effects in rabbits.

Key words: anti-inflammatory, leporids, spinal cord, neurotoxicity.
\end{abstract}

Efeitos sistêmicos e neurotóxicos do meloxicam por via epidural em coelhos

RESUMO: $O$ objetivo desse estudo foi avaliar as alterações sistêmicas e neurotóxicas promovidas pelo meloxicam, administrado por via epidural, em coelhos. Foram utilizados 12 coelhos adultos, quatro machos e oito fêmeas, pensando em média 1,9 $\pm 0,1 \mathrm{~kg}$. Os animais foram divididos equitativa e aleatoriamente em dois grupos, os quais receberam dose única de solução de $\mathrm{NaCl} 0,9 \%$ no volume de $0,3 \mathrm{~mL} \mathrm{~kg}^{-1}$, por via epidural (grupo controle - GC) ou meloxicam $\left(0,2 \mathrm{mg} \mathrm{kg}{ }^{-1}\right.$ ) associado à solução de $\mathrm{NaCl} \mathrm{0,9 \% ,} \mathrm{compondo} \mathrm{um} \mathrm{volume} \mathrm{total} \mathrm{de} 0,3 \mathrm{~mL} \mathrm{~kg}^{-1}$ (grupo meloxicam - GM). Avaliaram-se frequências cardíaca e respiratória, temperatura corporal e alterações neurológicas, antes da administração da anestesia (H0), uma, duas, três, seis, 12 e 24 horas após a punção epidural (H1, H2, H3, H6, H12 e H24, respectivamente) e a cada 24 horas após o H24, até o $10^{\circ}$ dia após a punção epidural (D2, D3, D4,D5, D6, D7, D8, D9 e D10). Mensurou-se ainda a temperatura superficial da região lombossacra em HO, H1, H6, H12, H24, D5 e D10. Realizou-se eutanásia em três animais de cada grupo no 15o e no 30o dia após o início do experimento, para avaliação das possíveis lesões medulares. As variâncias observadas nos parâmetros fisiológicos não foram sugestivas de efeito adverso do meloxicam, pois estiveram dentro do padrão de referência e não houve alterações físicas ou comportamentais. O exame neurológico se mostrou semelhante entre os grupos, havendo diferença apenas entre a avaliação inicial e uma hora após a epidural em ambos os grupos. Na histopatologia não houve alterações no GM e apenas um animal do GC apresentou discreto infiltrado linfoplasmocitário. A administração epidural lombossacra de meloxicam, na dose de $0,2 \mathrm{mg} \mathrm{kg}{ }^{-1}$, não causa efeitos sistêmicos e neurotóxicos significativos, em coelhos. Palavras-chave: anti-inflamatório, leporino, medula espinhal, neurotoxicidade.

\section{INTRODUCTION}

Nonsteroidal anti-inflammatory drugs (NSAIDs) effectively control pain through central and peripheral actions. In recent years, the use of NSAIDS to promote analgesia by the spinal route has been extensively researched (ORLANDO, 2011). MOURA (2015) administered meloxicam in the subarachnoid space in rats at a dosage of $30 \mu \mathrm{g}$ per animal and observed no systemic side effects or behavioral or neurological disorders in animals during the evaluation period. However, 
the experimental dose was insufficient to suppress induced hyperalgesia, suggesting the need for a larger dose to achieve the desired analgesic effect in the spinal cord, even though a larger dose could trigger neurotoxic effects.

NSAIDs present an alternative to the use of opioids, as these drugs cause fewer side effects, such as respiratory depression and vomiting, which often occur with the use of opioids (FANTONI $\&$ MASTROCINQUE, 2009). One of the main advantages of the epidurally administered NSAID is the discreet action in the gastric, renal, and hepatic systems in addition to platelet aggregation and fewer obvious side effects (CANDUZ et al., 2006). However, it is necessary to evaluate the toxicity of any substance that will be in contact with the central nervous system, as each drug has different characteristics and promotes specific actions in the cell, which can undermine spinal cord surgery (MOURA, 2015).

Meloxicam is an effective analgesic that is selective for cyclooxygenase-2 with well-established efficacy and safety, and, when administered preemptively, promotes better analgesia than buprenorphine (GASSEL et al., 2005). This drug is also effective when administered epidurally to promote trans- and postoperative analgesia, as reported by TAVAKOLI (2014). However, prior to the wide-spread use of meloxicam epidurally, detailed preclinical studies are necessary, particularly to avoid potentially irreversible neurotoxicity. The rabbit is commonly used for this purpose, as it is easy to obtain, house, and monitor (CANDUZ et al., 2007).

There are few reports in the literature regarding clinical and neurological changes in response to the epidural administration of meloxicam, and no study has assessed possible formation of histopathological lesions or neurotoxicity associated with a therapeutic dose. Therefore, the aim of this study was to assess the possible systemic and neurotoxic effects of epidural administration of meloxicam to rabbits at a dose of $0.2 \mathrm{mg} \mathrm{kg}^{-1}$.

\section{MATERIALS AND METHODS}

A total of 12 healthy New Zealand adult rabbits (four males and eight females; average mass, $1938 \pm 0.1 \mathrm{~g})$ were purchased from a commercial hatchery and housed in a animal facility at the Veterinary Hospital of the Universidade Federal de Campina Grande (Campina Grande, PB, Brazil).

Animals were dewormed with oral 5\% albendazole $^{\mathrm{a}}$ at a dose of $15 \mathrm{mg} \mathrm{kg} \mathrm{kg}^{-1}$ and then acclimated in individual cages for seven days before the study started. Each animal was fed with a 40 grams commercial food ${ }^{\mathrm{b}}$ twice per day and had water ad libitum.

Rabbits were randomly distributed in two experimental groups: a control group (GC), which received $0.3 \mathrm{~mL} \mathrm{~kg}^{-1}$ of $0.9 \% \mathrm{NaCl}$ epidurally, and a meloxicam group (GM), which received $0.2 \mathrm{mg} \mathrm{kg}^{-1}$ of $2 \%$ meloxicam $^{\mathrm{c}}$ diluted in $0.9 \% \mathrm{NaCl}$ epidurally, in a total volume of $0.3 \mathrm{~mL} \mathrm{~kg}^{-1}$.

After withholding food and water for 6 and $3 \mathrm{~h}$, respectively, the lumbosacral area was clipped. Animals were anesthetized with $5 \mathrm{mg} \mathrm{kg} \mathrm{kg}^{-1}$ xylazine $^{\mathrm{d}}$ and $40 \mathrm{mg} \mathrm{kg}^{-1} \mathrm{ketamine}^{\mathrm{e}}$, intramuscularly. After $15 \mathrm{~min}$, animals were placed in sternal recumbency, with the hind limbs cranially extended to accommodate a lumbosacral epidural puncture. After antisepsis with $0.5 \%$ chorhexidine ${ }^{f}$ solution, an epidural puncture was made in the lumbosacral space with a $22 \mathrm{G}^{\mathrm{g}}$ intravenous catheter needle, which was confirmed by rupture of the yellow ligament and the absence of resistance when administrating the solution. Each epidural injection was performed within 90 seconds by the same anesthesiologist who was unaware of the protocol. Animals remained in lateral recumbency for 10 minutes to complete spread of the solution in the epidural space, and then they were kept in this position until full recovery.

The following parameters were evaluated: heart rate (HR) (in beats per minute) using a clinical stethoscope $^{\text {h }}$, respiratory rate (RR) (in breaths per minute), by observing chest movements for $1 \mathrm{~min}$, rectal temperature ${ }^{i}$ (RT) (in degrees Celsius), measured with clinical digital thermometer, and surface temperature (ST), in Celsius degrees, using a thermographic ${ }^{j}$ camera with automatic calibration and emissivity of 0.98 . Images of the lumbosacral region of each animal were captured. Each generated thermogram was recorded on a memory card and later analyzed using Smartview software ver. 3.1 to obtain the average temperature of each region studied.

$\mathrm{HR}, \mathrm{RR}$, and RT were evaluated prior to of anesthesia administration (H0), 1, 2, 3, 6, 12, and 24 $\mathrm{h}$ following epidural puncture (H1, H2, H3, H6, H12, and $\mathrm{H} 24$, respectively), and every $24 \mathrm{~h}$ afterward until day 10 (D2, D3, D4, D5, D6, D7, D8, D9 and D10, respectively). ST was recorded at $\mathrm{H} 0, \mathrm{H} 1, \mathrm{H} 6, \mathrm{H} 12$, H24, D5 and D10. Evaluations were performed in the same environment in which the animals were kept during a $4 \mathrm{~h}$ period prior to the measurements to adapt to room temperature, which was controlled at $22^{\circ} \mathrm{C}$.

Neurological examinations were performed from $\mathrm{H} 0$ to D10 to observe behavioral changes, 
urination and defecation disorders, neurological function, motor function, and pain sensitivity. Motor function was based on criteria established by DRUMMOND \& MOORE (1989), which was classified as follows: 3 = free movement in hind limbs (HL); 2 = asymmetry, limited support of the body, and change in HL; 1 = inability to control body movement; and $0=$ paralysis of the HL. Tenderness was assessed by gripping the webbing of the fore and hind limbs, and the skin of the dermatomes sacral, lumbar, and thoracic regions with a toothed anatomical forceps $(16 \mathrm{~cm})$. Indicative signs indicative of pain and changes in posture were assessed using the methods reported by LEMOS (2014).

To identify suspected spinal injuries, three animals from each group were randomly chosen and euthanized on days 15 and 30 after epidural puncture. Euthanasia was performed by intramuscular administration of $5 \mathrm{mg} \mathrm{kg}^{-1}$ of xylazine and $40 \mathrm{mg} \mathrm{kg}^{-1}$ of ketamine, after 15 min it was administered intravenously $5 \mathrm{mg} \mathrm{kg}^{-1}$ of $1 \%$ propofol $^{\mathrm{k}}$, then it was held intracardiac administration of $100 \mathrm{mg} \mathrm{kg}^{-1}$ of $19.1 \%$ potassium chloride. The spinal cord of each animal was removed in less than three min after euthanasia to avoid risk of tissue injury through apoptosis or postmortem ischemia and then were evaluated macroscopically. Then, 5-mm segments of the thoracic, in the space between vertebrae TI2 and T13, and lumbar, between L6 and L7, spine were collected and stored in $10 \%$ formaldehyde for 12 days. Slides were prepared, stained with hematoxylin and eosin, and evaluated by the same pathologist, who was blinded to the experimental group, for the presence or absence of lesions in accordance with the following guidelines: type of lesion ( 1 = arachnoiditis; 2 = arachnoiditis and nerve injury; 3 = nerve damage); extent of damage $(1=<10 \% ; 2=10 \%-50 \% ; 3=>50 \%)$; lesion depth $(1=$ white matter; $2=$ gray matter; $3=$ white and gray matter); and blood vessel morphology $(1=$ normal, $2=$ with fibrous thickening, $3=$ with thrombosis). Also, the presence of adhesive arachnoiditis was rated as to: adherence $(0=$ none, $1=$ dura $(\mathrm{D})+\operatorname{arachnoid}(\mathrm{A}) ; 2=+$ pia mater $(\mathrm{R}) ; 3=\mathrm{D}+\mathrm{A}+\mathrm{R})$; thickening of the meninges $(0=$ absent; $1=$ low; $2=$ moderate; $3=$ high $)$; lymphocytic infiltration $(0=$ absent; $1=$ low; 2 $=$ moderate; 3 = high $)$; and fibrosis $(0=$ absent; $1=$ mild; 2 = moderate; $3=$ intense). Presence of nerve damage was evaluated as follows: $1=$ vacuolization; 2 = lymphocytic infiltration; $3=$ macrophage infiltration.
Bio Estat 5.0 software (<http://bioestat. software.informer.com/5.0/>) was used for data analysis. A probability ( $p)$ value of $<0.05$ was considered statistically significant. Clinical parameters at each time point within each group were evaluated by two-way analysis of variance with multiple comparisons followed by the Tukey test. Comparisons of parameters between groups at each experimental time point were performed using the Student's $t$-test. For the histological evaluation, a descriptive analysis was performed of the results of both groups. Data are presented as the mean \pm standard deviation.

\section{RESULTS AND DISCUSSION}

Groups were homogeneous with regard to weight, and consequently, the volume of solution administered was similar. Average weights and volumes administered were $1.8 \pm 0.1 \mathrm{~kg}$ and 0.5 $\pm 0.04 \mathrm{~mL}$, respectively, in the control group and $1.9 \pm 0.1 \mathrm{~kg}$ and $0.6 \pm 0.03 \mathrm{~mL}$, respectively, in the experimental (GM) group.

There were no significant differences in HR between time points, only intergroup differences, with lower values for the GM group (Table 1). However, this finding was not important because the values remained within physiological limits for the species in both groups (VILARDO, 2006). With respect to RT, there were variations between groups (Table 1). The $\mathrm{H} 1$ values were lower than those at $\mathrm{H} 0$, which was probably due to dysregulation of the thermoregulatory center, and the muscle relaxant effects of xylazine associated with potentiation by ketamine (LIMA et al., 2014). The RR values were high since the start of the experiment, indicating stress in the animals, in accordance with the report by LIMA et al. (2014). At H1 lowest values were seen, particularly in the meloxicam group (GM), this may be due to the action of anesthetic drugs as well as for a possible depressor effect of meloxicam in the respiratory system. Although, possible effects of meloxicam on this and other parameters cannot be ruled out, these findings lack clinical importance, since above parameters remained within normal ranges for the specie (REECE, 1999; SCHANAIDER \& SILVA, 2004).

Thermography was performed to detect changes in local temperatures that could be associated with inflammation or spinal cord injury, since the motor nerve fibers control skin microcirirculation by means of vasoconstriction or vasodilation, 
Table 1 - Mean \pm standard deviation of the heart rate (HR), respiratory rate (RR), rectal temperature (RT), and surface temperature (ST) in rabbits in the control group $\left(0.9 \% \mathrm{NaCl}\right.$ solution at $\left.0.3 \mathrm{~mL} \mathrm{~kg}^{-1}\right)(\mathrm{GC})$ and the meloxicam group $\left(0.2 \mathrm{mg} \mathrm{kg}^{-1}\right.$ of meloxicam in $0.9 \%$ $\mathrm{NaCl}$ solution at $0.3 \mathrm{~mL} \mathrm{~kg}^{-1}$ ).

\begin{tabular}{|c|c|c|c|c|c|c|c|c|}
\hline \multirow[t]{2}{*}{ Times } & \multicolumn{2}{|c|}{----------HR (bpm)---------- } & \multicolumn{2}{|c|}{---------RR (mpm)------' } & \multicolumn{2}{|c|}{--------RT $\left({ }^{\circ} \mathrm{C}\right)-------$} & \multicolumn{2}{|c|}{-----ST $\left({ }^{\circ} \mathrm{C}\right)$} \\
\hline & GC & GM & $\mathrm{GC}$ & GM & $\mathrm{GC}$ & GM & $\mathrm{GC}$ & GM \\
\hline Ho & $215 \pm 21$ & $201 \pm 15$ & $174 \pm 31$ & $196 \pm 58$ & $39.3 \pm 0.6$ & $39.5 \pm 0.6$ & $35.4 \pm 0.8$ & $35.5 \pm 0.9$ \\
\hline H1 & $199 \pm 34$ & $187 \pm 17$ & $97 \pm 49$ & $65 \pm 15^{*}$ & $37.3 \pm 0.7^{*}$ & $36.7 \pm 1.2^{*}$ & $35.0 \pm 0.9$ & $35.3 \pm 0.5$ \\
\hline $\mathrm{H} 2$ & $211 \pm 16$ & $186 \pm 29$ & $207 \pm 72$ & $131 \pm 78$ & $38.5 \pm 0.8^{\mathrm{a}}$ & $37.0 \pm 1.2^{\mathrm{b}}$ & - & - \\
\hline H3 & $220 \pm 15^{\mathrm{a}}$ & $187 \pm 30^{b}$ & $160 \pm 54$ & $138 \pm 48$ & $39.4 \pm 0.4$ & $37.4 \pm 0.9$ & - & - \\
\hline H6 & $223 \pm 32$ & $202 \pm 10$ & $236 \pm 49^{\mathrm{a}}$ & $156 \pm 36^{\mathrm{b}}$ & $38.7 \pm 1.0$ & $39.3 \pm 0.9$ & $35.1 \pm 0.8$ & $34.8 \pm 0.3$ \\
\hline H12 & $217 \pm 25$ & $197 \pm 19$ & $231 \pm 35^{\mathrm{a}}$ & $173 \pm 31^{\mathrm{b}}$ & $39.1 \pm 0.3$ & $39.3 \pm 0.6$ & $35.1 \pm 0.4$ & $34.7 \pm 0.5$ \\
\hline H24 & $221 \pm 30$ & $213 \pm 21$ & $193 \pm 44$ & $208 \pm 47$ & $39.1 \pm 0.5$ & $38.7 \pm 0.8$ & $34.7 \pm 0.5$ & $35.1 \pm 0.6$ \\
\hline D2 & $243 \pm 26^{a}$ & $205 \pm 12^{b}$ & $251 \pm 50$ & $200 \pm 41$ & $39.0 \pm 0.3$ & $38.8 \pm 0.5$ & - & - \\
\hline D3 & $237 \pm 13$ & $218 \pm 18$ & $218 \pm 69$ & $204 \pm 42$ & $39.4 \pm 0.4$ & $39.3 \pm 0.6$ & - & - \\
\hline D4 & $230 \pm 16$ & $224 \pm 38$ & $257 \pm 57$ & $240 \pm 62$ & $39.1 \pm 0.3$ & $38.9 \pm 0.9$ & - & - \\
\hline D5 & $243 \pm 21$ & $223 \pm 36$ & $254 \pm 50$ & $227 \pm 55$ & $39.2 \pm 0.4$ & $39.5 \pm 0.8$ & $36.6 \pm 0.4$ & $36.1 \pm 0.7$ \\
\hline D6 & $253 \pm 40$ & $233 \pm 23$ & $261 \pm 72$ & $218 \pm 44$ & $38.9 \pm 0.4$ & $39.1 \pm 0.7$ & - & - \\
\hline D7 & $244 \pm 24$ & $249 \pm 39$ & $247 \pm 38$ & $256 \pm 64$ & $38.9 \pm 0.9$ & $39.1 \pm 0.8$ & - & - \\
\hline D8 & $236 \pm 24$ & $209 \pm 32$ & $257 \pm 48$ & $249 \pm 45$ & $39.2 \pm 0.5$ & $39.1 \pm 0.7$ & - & - \\
\hline D9 & $250 \pm 49$ & $235 \pm 52$ & $235 \pm 50$ & $217 \pm 73$ & $38.9 \pm 0.8$ & $39.0 \pm 0.9$ & - & - \\
\hline D10 & $234 \pm 23$ & $208 \pm 25$ & $203 \pm 51$ & $225 \pm 57$ & $39.1 \pm 0.4$ & $39.2 \pm 0.8$ & $37.9 \pm 0.8^{*}$ & $37.8 \pm 0.6^{*}$ \\
\hline
\end{tabular}

Abbreviations: bpm, beats per minute; mpm, movement per minute; ${ }^{\circ} \mathrm{C}$, degrees Celsius. ${ }^{*}$ Statistically different from $\mathrm{H} 0$ in the same group $(P<0.05) ; \mathrm{a}, \mathrm{b}$ - different letters indicate statistical differences between groups at the same time points $(P<0.05)$.

causing greater or lesser irrigated regions. Also, any nerve or microvascular dysfunction will change the tone of the innervated area, which can be diagnosed by variations in skin temperature (BRIOSCHI et al., 2003). The ST did not vary between groups but increased on D10 compared to $\mathrm{H} 0$ in both groups (Table 1 and Figure 1). Considering that the laminae acts as a thermal insulator, its absence in the lumbosacral region facilitated heat loss in this location (RESENDE et al., 2012). This fact explained the significant increase in surface temperature observed on D10, which was associated with growth of the coat, corroborating the findings of FAÇANHA et al. (2010), who attributed density and size as factors contributing to changes in ST. The literature is rather sparse with respect to ST in rabbits. In this study, when comparing ST with RT, a considerable decrease in ST from the initial assessment was noticed, although this difference did not reach statistical significance. These observations were also reported by SOUZA et al. (2006), suggesting that decreased ST is a common feature of this assessment.

No behavioral changes or voiding or defecation dysfunctions were observed. Motor asymmetry changes, restriction, and inability to sustain the body were observed in both groups at H1. It was unclear whether these changes were caused by neurological injuries or were due to dissociative anesthesia, since such alterations occurred approximately $90 \mathrm{~min}$ after administration of anesthesia and the animals had not completely recovered at the time of testing, in agreement with the report by LIMA et al. (2014). Cutaneous sensitivity was present in all animals during all evaluations. Absence of relevant neurological disorders in the study is in agreement with the report by TAVAKOLI (2014), who observed no clinical evidence of neurological complications following epidural administration of meloxicam in dogs, suggesting the relative safety of this drug via the epidural route. 


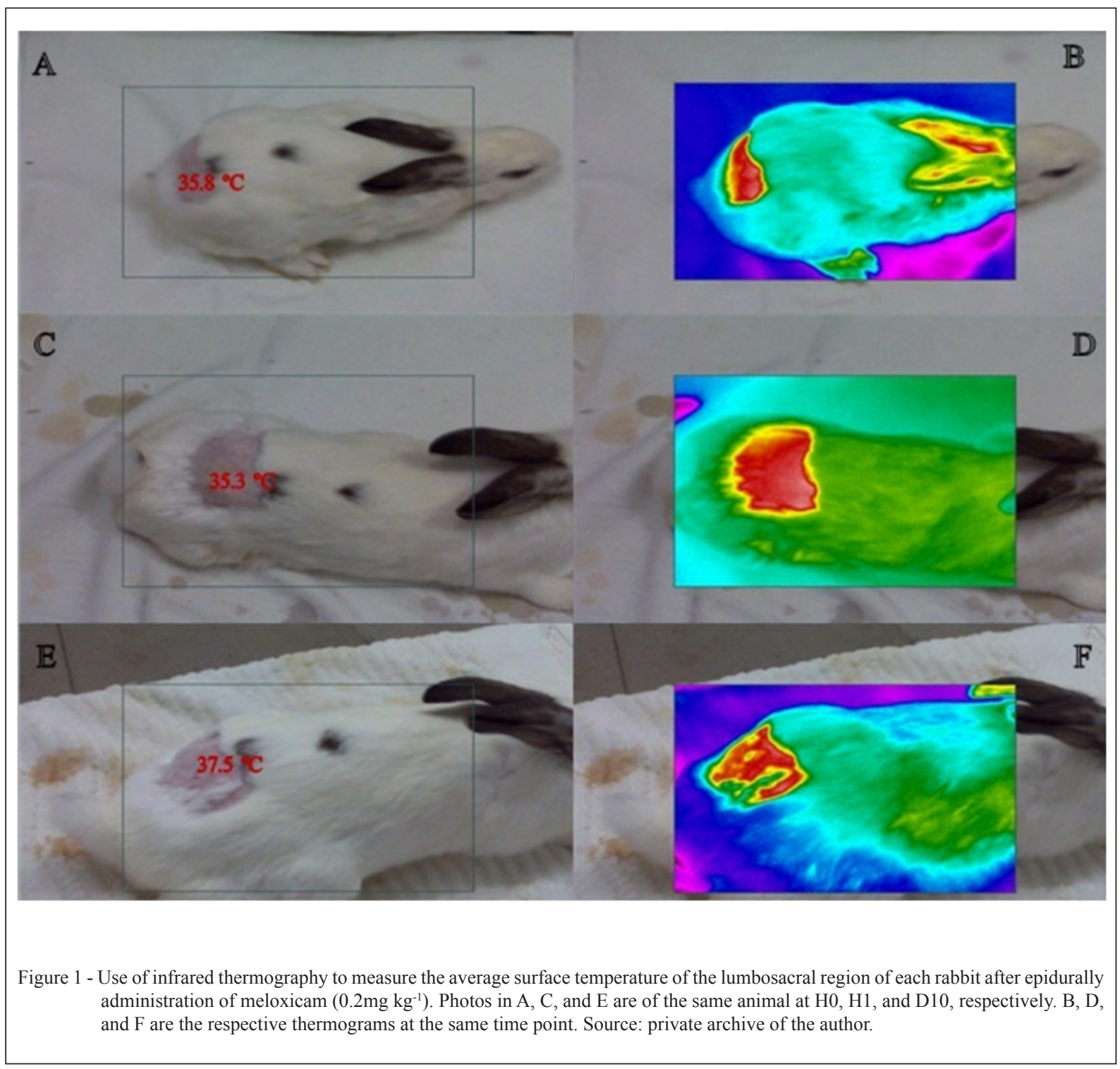

Histologically, there were no pith or meninges lesions in any animal $(0 / 6)$ in the GM group. In the control group, one animal $(1 / 6)$ euthanized on day 15 after the epidural presented arachnoiditis (1) with extent of damage (1) and blood vessel morphology normal (1). Discrete focus of lymphocytic infiltration in the meninges was also observed (1) (Figure $2)$. There was no adherence, thickening or fibrosis of the meninges or nerves damages of this and other animals of the GC group. This observation was not due to the administered volume, since the volume was the same in both groups, but rather a possible mild inflammatory reaction due to the epidural puncture itself. Histopathology confirmed the results of the clinical and neurological reviews, increasing the possibility that meloxicam can be safely administered by the epidural route, as reported by TAVAKOLI (2014). 


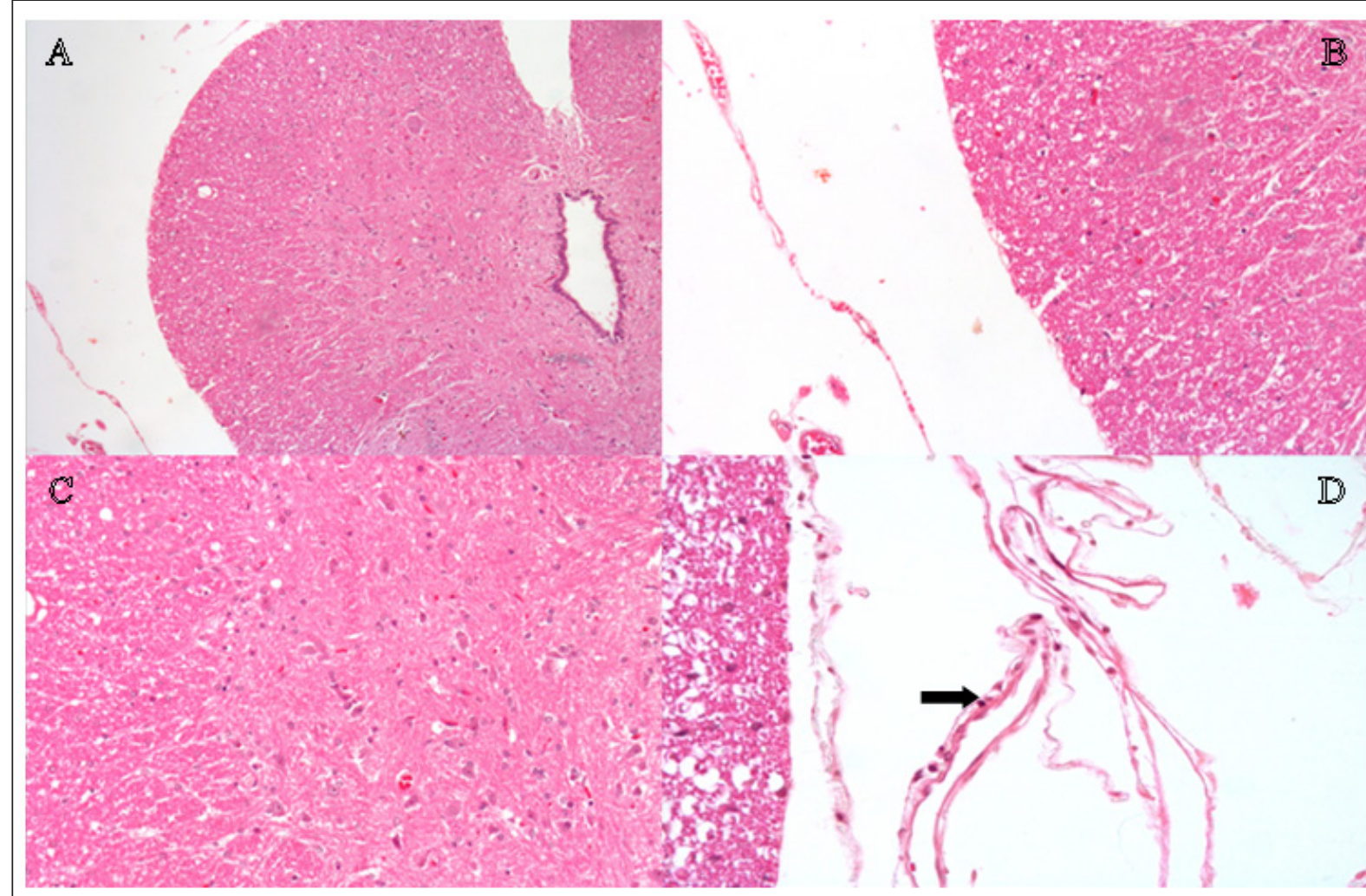

Figure 2 - Histological sections of the rabbit spinal cord following epidurally administration of $0.9 \% \mathrm{NaCl}$ solution. A, B, and C: Note the absence of lesions in the spinal parenchyma and meninges adhesion. D: Note the discrete and focal infiltration of lymphocytes (arrow). HE staining. A: $200 \times$ magnification and B, C, and D: 400×magnification. Source: private archive of the author.

\section{CONCLUSION}

Epidural lumbosacral administration of meloxicam at a dose of $0.2 \mathrm{mg} \mathrm{kg}^{-1}$ caused no significant systemic or neurotoxic effects in rabbits. Although epidural administration of meloxicam appears to be safe, further research is needed to assess anti-inflammatory and analgesic effects.

\section{SOURCES AND MANUFACTURES}

a. Magzole 5\%, Leiva Milk A/S Chemical and Biological Industries;

b. Rations Algomix, Algomix;

c. Maxicam injectable $2 \%$ fine gold

d. Injectable Xilazin $2 \%$ Syntec;

e. Injectable Cetamin $10 \%$ Syntec;

f. Riohex $0.5 \%$ Rioquímica;

g. Cateter Nipro 22G, Nipro Medical, Ltd;

h. Estetoscópio Littman Classic II Pediatric, WMB E Comércio, Ltd;

i. Digital Termômetro with rigid tip, THGT150B;

j. Termovisor Fluke Ti25, Fluke;

k. Propovan 1\% Cristália Pharmaceutical Chemicals, Ltd;

1. Solução potassium chloride $19.1 \%$, Isofarma.

\section{BIOTHICS \\ AND \\ BIOSSECURITY COMMITTEE APPROVAL}

The study protocol was approved by the Ethics and Research Committee of the Universidade Federal de Campina Grande (protocol no. 003/2016).

\section{ACKNOWLEDGEMENTS}

To Conselho Nacional de Desenvolvimento Científico e Tecnológico (CNPq) for productivity scholarship of Pedro Isidro da Nóbrega Neto and doctoral scholarship of Gracineide da Costa Felipe.

\section{REFERENCES}

BRIOSCHI, M.L. et al. Cutaneous thermometry: new concepts. Jornal Vascular Brasileiro, v.2, n.2, p.151-160, 2003. Available from: < http://jornalvascularbrasileiro.com.br/03-02-02/03-02-02151/03-02-02-151.pdf $>$. Accessed: Jan. 15, 2016. doi: 03-0202/03-02-02-151/03-02-02-151.

CANDUZ, B. et al. Epidurally lornoxicam administration innocent. Journal of Clinical Neuroscience, v.14, n.10, p.968974, 2007. Available from: <www.researchgate.net/profile/ Yigit_Uyanikgil2/publication/6017465_Epidurally_lornoxicam_ 
administration_--_innocent/links/0fcfd5007dad1c18f8000000. pdf>. Accessed: Jan. 13, 2016. doi: 6017465.

DRUMMOND, J.C.; MOORE, S.S. The influence of dextrose administration on neurological outcome after spinal cord temporary ischemia in the rabbit. Anesthesiology, v.70, n.1, p.64-70, 1989. Available from: <http://ether.stanford.edu/ library/neuroanesthesia/Journal\%20Articles/Moore_The\%20 influence $\% 20$ of $\% 20 \mathrm{dex}$ trose $\% 20$ administration.pdf $>$. Accessed: Jan. 12, 2016.

FAÇANHA, D.A.E. et al. Annual variation of morphological characteristics and coat surface temperature of Holstein cows in semi-arid environment. Journal of Animal Science, v.39, n.4, p.837-844, 2010. Available from: <http://www.scielo.br/ scielo.php?script $=$ sci_arttext\&pid=S15163598201000040002 $0 \&$ lang $=$ en $>$. Accessed: Jan. 11, 2016. doi: 10.1590/S151635982010000400020 .

FANTONI, D.T.; MASTROCINQUE, S.R.G. Pathophysiology and control of acute pain. In: FANTONI, D.T.; MASTROCINQUE, S.R.G. Anesthesia in dogs and cats. Sao Paulo: Roca, 2009. p.521-544.

GASSEL, D.A. et al. Comparison of oral and subcutaneous small animals administration of buprenorphine and meloxicam for preemptive analgesia in cats undergoing ovariohysterectomy. Jornal American Veterinary Medical Association, v.227, n.12, p.1937-1944, 2005. Available from: <http://avmajournals.avma. org/doi/abs/10.2460/javma.2005.227.1937>. Accessed: 12, Jan. 2016. doi: $10.2460 /$ javma.2005.227.1937.

LEMOS, M.F. Effects of subarachnoid methotrexate on spinal cord and meninges of rabbits. 2014. 58f. Thesis (Doctorate in Anesthesiology) - Faculty of Veterinary Medicine, Universidade Estadual Paulista, SP, Brazil.

LIMA, D.A.S.D. et al. Comparative study of Ketamine association with dexmedetomidine, Medetomidine or Xylazine in rabbits. Brazilian Journal of Veterinary Medicine, v.36, n.1, p.35-41, 2014. Available from: $<$ http://www.rbmv.com.br/pdf artigos/2409-2014 15-24451RBMV008.pdf>. Accessed: Oct. 24, 2014. doi: 1551008 .
MOURA, L.F.L. et al. Subarachnoid meloxicam does not inhibit the mechanical hypernociception on carrageenan test in rats. Brazilian Journal of Anesthesiology, v.65, n.2, p.124-129, 2015 Available from: <http://www.scielo.br/scielo.php?pid=S003470942015000200124\&script=sci_arttext $>$. Accessed: Jan. 12, 2016. doi: 10.1016/j.bjane.2013.10.020.

ORLANDO, C.F.P. Induced neurotoxicity analgesics. 2011. 37f. Seminar (Postgraduate Diploma in Animal Science) - School of Veterinary and Animal Science, Federal University of Goiás, Goiânia, Brazil.

REECE, W.O. Regulação da temperatura e fisiologia ambiental. In: SWENSON, M.J.; REECE, W.O. Fisiologia dos animais domésticos. Rio de Janeiro: Guanabara Koogan, 1999. Cap.47, p.805-813.

RESENDE, L.H.C. et al. Shorn of rabbits as an alternative to improve the thermal comfort. Fazu in Review, n.9, p.85-89, 2012. Available from: $<\mathrm{http}: / /$ www.fazu.br/ojs/index.php/fazuemrevista/ article/view/399/407>. Accessed: Jan. 12, 2016. doi: 399/407.

SCHANAIDER, A.; SILVA, P.C. Use of animals in experimental surgery. Acta Brazilian Surgery, v.19, n.4, p.441-447, 2004. Available from: <http://www.scielo.br/scielo.php?script=sci_ar ttext\&pid $=\mathrm{S} 010286502004000400014 \& \operatorname{lng}=\mathrm{en} \& \mathrm{nrm}=\mathrm{iso}>$. Accessed: Jan. 11,2016. doi: 10.1590/S0102-86502004000400014.

SOUZA, B.B. et al. Physiological parameters and heat tolerance index of beef cattle Sindhi in Paraiba semiarid. Science and Agrotecologia, v.31, n.3, p.883-888, 2006. Available from: <http:// www.scielo.br/pdf/\%0D/cagro/v31n3/a40v31n3.pdf $>$. Accessed: Feb. 12, 2016. doi: 10.1590/S1413-70542007000300040.

TAVAKOLI, A. The epidural analgesic effects of meloxicam in dogs. Iranian Journal of Veterinary Science and Technology, v.6, n.1, p.58-69, 2014. Available from: <https://ijvst.um.ac.ir/ index.php/veterinary/article/view/18912>. Accessed: Jan. 13, 2016. doi: 18912

VILARDO, S.E.F. Lagomorpha (Coelho, Lebre, Lebre-assobiadora). In: ZALMIR, S.C. et al. Tratado de animais selvagens - Medicina Veterinária. São Paulo: Roca, 2006. p.415- 431. 